VOX PATRUM 23 (2003) t. 44-45

\author{
Alicja STEPNIEWSKA \\ (Lublin, KUL)
}

\title{
SYLWIA - MATKA PAPIEŻA GRZEgORZA WIELKIEGO
}

Grzegorz Wielki, w przeciwieństwie do św. Augustyna, niewiele miejsca poświęcił swojej matce, Sylwii. Biskup Hippony zwłaszcza w autobiograficznych Wyznaniach wielokrotnie podkreśla ogromną rolę matki Moniki w ksztaltowaniu jego skomplikowanej osobowości, Grzegorz natomiast wspomina bezimiennie swoją matkę tylko raz. Zresztą droga życiowa tych dwóch wielkich Ojców Kościoła była zupełnie inna.

W 38 Homilii na Ewangelię, wygłoszonej w 592 r. w rzymskiej bazylice św. Klemensa Męczennika, Grzegorz sporo informacji podaje o trzech siostrach swego ojca - Tarsylii, Gordianie i Emilianie, które imiennie wymienia i szczegółowo charakteryzuje ${ }^{1}$. Opisując niemoc i śmierć Tarsylii, wyróżniającej się wyjątkową świętością, podaje:

${ }^{1}$ Por. In Evangelia hom. 38, 15, PL 76, 1290D-1292A, tłum. W. Szołdrski, PSP 3, 302-303: „Mój ojciec miał trzy siostry; wszystkie trzy byly dziewicami poświęconymi Bogu. Jedna z nich miała imię Tarsylia, druga Gordiana, trzecia Emiliana. Wszystkie żarliwie starały się o doskonałość: równocześnie poświęciły się Bogu i trzymając się surowej reguły żyły wspólnie we własnym domu. Żyjąc tak przez czas dłuższy Tarsylia i Emiliana z każdym dniem czynily postępy w kochaniu swego Stwórcy i będąc tutaj tylko ciałem, codziennie duchem zajmowały się tym, co jest wieczne. Przeciwnie zaś Gordiana z każdym dniem w swej miłości oziębiała się coraz bardziej i powoli nawracała do kochania tego świata [...]. Pewnej nocy owej Tarsylii, mojej ciotce, która wśród swoich sióstr odznaczała się ustawiczną modlitwą, powagą życia, szczególną wstrzemięźliwością i dosięgała szczytu świętości, ukazal się w widzeniu mój przodek, Feliks, biskup tego rzymskiego Kościoła i wskazując jej miejsce wiecznej chwały, powiedział: «Przyjdź, przyjmują cię bowiem do tego jaśniejącego mieszkania». Następnego dnia zachorowała na febrę i była bliską śmierci [...]. Nagle chora zwróciwszy oczy ku niebu widzi przychodzącego Jezusa i z wielkim wysiłkiem poczyna wołać do otaczających: «Odejdźcie, odejdźcie, Jezus przychodzi»! I gdy tak wpatrywała się w Tego, którego widziała, swięta owa dusza opuściła ciało [...]. Gdy jej zwłoki, jak to zwykle u zmarłych się dzieje, rozebrano dla obmycia, okazało się, iż wskutek długich modlitw jej skóra na łokciach i kolanach była tak twarda jak skóra wielbłąda. I tak martwe jej ciało świadczyło, co jej duch zawsze czynił za życia. Stało się to przed dniem narodzenia Pana. Gdy przeminąl, ukazała się w widzeniu swej siostrze Emilianie i tak doń powiedziała: «Przyjdź, ponieważ dzień urodzin Pana obchodziłam bez ciebie, dzień objawienia Pana obchodzić będę z tobą» [...]. Po tym widzeniu wnet przyszła choroba i jak było powiedziane, gdy niemoc zwiększała się coraz bardziej, umarła w przeddzień 
„Następnego dnia [Tarsylia] zachorowała na febrę i była bliską śmierci. A jako przy zgonie znakomitych niewiast i mężczyzn wielu przychodzi, aby pocieszać swych bliskich, tak i w godzinę jej śmierci otoczylo jej łóżko wielu mężczyzn i wiele kobiet, wśród których była też i moja matka (inter quas mater mea quoque adfuit)" ${ }^{\prime 2}$.

Jest to jedyne miejsce w bogatej twórczości Grzegorza, gdzie on sam mówi o swej matce, nie wymieniając nawet jej imienia. Ten sam epizod opowiedziany później w Dialogach ${ }^{3}$, napisanych w 594 r., nie wspomina już matki, z czego możemy wnioskować, że już w tym czasie nie żyła. Dziwi nas nieco, że on wywodzący siç ze starej patrycjuszowskiej tradycyjnej rodziny rzymskiej Anicjuszów (gens Anicia) ${ }^{4}$, posiadającej w swej historii nawet biskupa Rzymu papieża Feliksa III $(483-492)^{5}$, poświęcający ciotkom, jak żaden $\mathrm{z}$ autorów

Objawienia Pańskiego. Co do Gordiany, to ta widząc się samą stawała się coraz gorszą i to, co przedtem kryło się w grzesznych pragnieniach, potem okazało się $w$ złych czynach. Zapomniala bowiem o bojaźni Bożej, o wstydzie i swej godności, zapomniała o swym ślubie dziewictwa i potem wyszła za mąż za dzierzawcę dóbr swoich. Oto wszystkie trzy pierwej płonęły tym samym pragnieniem świętości, jednakże nie wszystkie w tym wytrwaly, gdyż według słów Pana: «wielu jest wezwanych, ale malo wybranych»".

2 In Evangelia hom. 38, 15, PL 76, 1291c, PSP 3, 303. O św. Sylwii por. X. Barbier de Montault, Sainte Sylvie, ,Revue de l'Art Chrétien” 6 (1892) 302-303; E. Wuescher-Becci, Santa Silvia, madre di san Gregorio, e le sue memorie, , Rassegna Gregoriana” 3 (1904) 59-70; P. Batiffol, St. Grégoire le Grand, Paris 1928, 14, 16, 24-26, 29, 151; Vies des Saints, XI, Paris 1954, 95; G.B. Proja, Silvia, BS XI, Roma 1968, 1082-1081; A.P. Frutaz, LThK $^{2}$ IX 760; H. Grieser, LThK ${ }^{3}$ IX 590; A. Amore, ECat XI 601 .

${ }^{3}$ Por. Dialogi IV 17, 1, SCh 265, 68, thum. W. Szoldrski, PSP 2, 171-172: ,powtarzam i to co jak pamiętam, powiedziałem $w$ innych homiliach na Ewangelię o mojej ciotce Tarsylii. Dzięki swej cnocie, ciągłej modlitwie, poważnemu zapatrywaniu się na życie, przewyższała dwie inne swoje siostry i dosięgła szczytu uświęcenia. Ukazał się jej w widzeniu mój przodek Feliks, biskup tego Rzymskiego Kościoła i ukazując jej miejsce wiecznej chwały, tak powiedział: «Przyjdź, przyjmę cię bowiem do tego jaśniejącego mieszkania». Następnego dnia zachorowała na febrę i była bliską śmierci. A jako przy zgonie znakomitych niewiast i mężczyzn wielu jest obecnych, aby pocieszać bliskich, tak też w godzinę jej śmierci otoczyło jej lóżko wielu mężczyzn i wiele kobiet. Nagle oczy w górę zwróciła, a ujrzawszy przychodzącego Jezusa z wielkim wysiłkiem poczęła wolać do otaczających: «Odejdźcie, odejdźcie, Jezus przychodzi»! I gdy tak wpatrywała się w Tego, którego widziała, jej święta dusza opuściła ciało. Taki się zaraz roztoczył zapach, że ta przemiła wón okazała wszystkim, że tam przybył Twórca tego, co miłe. Gdy jej zwłoki, jak to zwykle ze zmarlymi się dzieje, rozebrano dla obmycia, okazało się, że z powodu długich modlitw jej skóra na lokciach i kolanach była tak twarda, jak skóra wielbłąda. I tak jej martwe ciało zaświadczyło, co jej duch zawsze czynil za życia”. O Emilianie zob. A. Amore, BS IV 1112; o Tarsylii zob. A. Amore, BS XIl 139; ECat XI 1777; LThK $^{2}$ IX 1303; Vies des Saints XII 643-644.

${ }^{4}$ Por. I. Schuster, Les ancêtres de saint Grégoire et leur sépulture de famille à $S$. Paul de Rome, „Revue Bénédictine" 21 (1904) 113-123; A. Ferma, Antichità cristiane. Gli antenati di san Gregorio Magno, „La Civiltà Cattolica” 115 (1964) IV 238-246; drzewo genealogiczne rodziny Grzegorza zob. Prosopography of the Later Roman Empire, III, ed. J.R Martindale, Cambridge 1992, 1545: R.A. Markus, Grzegorz Wielki, tłum. P. Nehring, Warszawa 2003, 21-28 (Grzegorz i jego rodzina).

5 Por. J.T. Milik, La famiglia di Felice III Papa, „Epigraphica” 28 (1966) 140-142. 
wczesnochrześcijańskich tak wiele miejsca, swoją matkę, która niewątpliwie z powodu jego słabego zdrowia ${ }^{6}$, troszczyła się o niego zapewne od początku, wspomina tylko raz. Może ze względu na pietyzm wobec niej chciał ją pozostawić otoczoną nimbem tajemnicy, a może poszedł za ówczesnym zwyczajem, że nawet wielcy twórcy rzadko w swoich pismach wspominali własne matki.

Późniejsze informacje źródłowe dotyczące matki Grzegorza są bardzo skąpe i pojawiają się przy okazji spisywanych jego biografii. Nie podaje ich także, przekazujący również wiele wiadomości o rodzinach papieży, kompilowany od poł. VI wieku Liber Pontificalis ${ }^{7}$ ani Beda Czcigodny (672-735) w swojej Historii Kościota ${ }^{8}$. Po raz pierwszy imię matki występuje w żywocie św. Grzegorza, napisanym $w$ latach 704-714 przez nieznanego mnicha $z$ angielskiego klasztoru w Whitby ${ }^{9}$. Wiadomości tej nie zaczerpnął on zapewne $z$ jakiegoś źródła pisanego (nie znal bowiem jeszcze nawet Historii Bedy), lecz prawdopodobnie $\mathrm{z}$ tradycji ustnej przechowywanej $\mathrm{w}$ Whitby lub Canterbury ${ }^{10}$. Wspomniany mnich informuje, że Grzegorz był „z pochodzenia Rzymianinem, z ojca Gordiana i matki Sylwii, szlachetnym według prawa, a jeszcze szlachetniejszym sercem w pobożności wobec Boga"11. Wiadomość tę powtarza pod koniec VIII wieku mnich benedyktyński z Monte Cassino Paweł Diakon, twórca drugiego z kolei Żywota Grzegorza ${ }^{12}$. Jan Diakon, autor trzeciego chronologicznie Żywota Grzegorza napisanego ok. 875 r., obeznany był niewątpliwie z powyższą tradycją, a wykorzystując wcześniejsze biograficzne relacje oraz pisma samego Grzegorza, rozszerzył jeszcze powyższą informację, dodając inne istotne szczegóły:

„Grzegorz, z pochodzenia Rzymianin, bjegły w filozofii, syn sławnego męża Gordiana i błogosławionej Sylwii (beatae Silviae filius), stal na czele stolicy Rzymskiej

${ }^{6}$ O swoich chorobach Grzegorz wielokrotnie wspominal w listach, por. Epistolae I 24, V 53a, IX 123, XIII 12; V. Paronetto, La cattiva salute di Gregorio Magno, OsRom 121 (1981) nr 73 (29 III), s. 3.

${ }^{7}$ Por. Liber Pontificalis 66, ed. L. Duchesne, I, Paris 1886 (ristamp. 1955) s. 312: „Gregorius natione Romanus, ex patre Gordiano, sedit ann. XIII mens. VI dies X".

${ }^{8}$ Por. Historia ecclesiastica gentis Anglorum II 1, PL 95, 75-81. Nie podają ich również wcześniejsze źródła o Grzegorzu, zob. Gregorius Turonensis, Historia Francorum X 1; Isidorus Hispalensis, De viris illustribus 40.

${ }^{9}$ Por. Liber beati et laudabilis viri Gregorii papae urbis Romae, ed. B. Colgrave: The earliest Life of Gregory the Great by an anonymous monk of Withby, text, translation and notes, Cambridge 1985, 72-139 (Latin text and translation).

${ }^{10}$ Por. tamże, s. 53 i 144 , n. 4.

11 Tamże, 1, s. 72: „Fuit igitur iste natione Romanus, ex patre Gordiano et matre Silvia, nobilis secundum legem sed nobilior corde coram Deo in religione".

${ }^{12}$ Por. Vita Gregorii Magni 1, PL 75, 41: „Gregorius hac urbe Romana, patre Gordiano, matre vero Silvia editus, non solum de spectabili senatorum prosapia, veram etiam religiosa, originem duxit...". 
13 lat, 6 miesięcy i 10 dni w czasach augustów - Tyberiusza Maurycjusza i Foki.

Zrodzony ze szlachetnego senatorskiego rodu, pochodził zarówno $\mathrm{z}$ najszlachetniejszej, jak i wysoce religijnej rodziny"13.

Późniejsi, zwłaszcza nowożytni biografowie, opierając się na przekazanych w listach Grzegorza informacjach o ufundowaniu przez niego na Sycylii 6 klasztorach i uposażeniu ich swoim majątkiem ${ }^{14}$ wnioskują, że Sylwia pochodziła $\mathrm{z}$ tych okolic i właśnie do niej należały wcześniej te posiadłości ${ }^{15}$, natomiast mąż jej, Gordian, pochodził z Rzymu, gdzie na wzgórzu Skaurusa (ad clivum Scauri) na Celius, posiadał duży i wygodny dom. Nie wiemy jednak nic o jej rodzinie, ani też nie znamy dokładnej daty jej narodzin; nastąpity one zapewne w 1. pot. VI wieku.

Sylwia $z$ Gordianem, pełniącym funkcję regionariusa, miała przynajmniej dwóch synów - Grzegorza i drugiego o nieznanym imieniu (może Germanus), który zrobił błyskotliwą karierę cywilną, zastępując w 590 r. brata na urzędzie prefekta Rzymu ${ }^{16}$. Grzegorz określa go w swej korespondencji kilkakrotnie słowami: „gloriosus frater meus palatinus patricius"17, a zostawszy papieżem radził się go niekiedy w sprawach publicznych, zwłaszcza dotyczących Sycylii.

Sylwia po śmierci męża Gordiana, która nastąpila prawdopodobnie w 570 roku, opuściła wkrótce ich dotychczasowy pałac i przeniosła się na Mały Awentyn, gdzie zamieszkała samotnie (iuxta portam beati Pauli Apostoli, loco qui dicitur Cella nova), czyli obok bramy św. Pawła Apostoła, w miejscu, które zwano Cella nova, a gdzie później wzniesiono kościół i klasztor św. Saby. Stąd to każdego dnia przez dwa lata, jak podaje dalej biograf, wysyłała synowi na Clivus Scauri porcję świeżych warzyw na srebrnej tacy ${ }^{18}$, co kontynuowała aż

${ }^{13}$ Por. Vita Gregorii Magni 1, PL 75, 63: „Gregorius genere Romanus, arte philosophus, Gordiani viri clarissimi et beatae Silviae filius, praefuit Romanae sedi annis tredecim, mensibus sex, diebus decem, temporibus Tiberii Mauricii et Phocae Augustorum. Iste, senatoria stirpe progenitus, tam nobilissimam quam religiosissimam generationem duxit...".

${ }_{14}$ Por. Gregorius Turonensis, Historia Francorum X 1, PL 71, 527, thum. K. Liman - T. Richter: Grzegorz z Tours, Historie. Historia Franków, Kraków 2002, 417: „Własnym kosztem ufundował na Sycylii sześć klasztorów. Zapisał im taką ilość ziemi, jaka wystarczała na codzienne utrzymanie. Resztę swego majątku sprzedał z całą obsadą domu i to rozdal ubogim". Informację tę przejął później Paweł Diakon (Vita Gregorii 3) i Jan Diakon (Vita Gregorii 15, PL 75, 65A): „sex monasteria in Sicilia fabricans, sufficientibus fratribus cumulavit quibus tantum praediorum contulit, quantum posset ad victum quotidianum Deo illic militantium sine indigentia suffragari".

15 Por. G.B. Proja, Silvia, BS XI 1082; A. Amore, Silvia, ECat XI 601.

16 Por. Gregorius Turonensis, Historia Francorum X 1, PL 71, 527; Prosopography of the Later Roman Empire, III, dz. cyt., s. 7 (Germanus); R.A. Markus, Grzegorz Wielki, dz. cyt., s. 2122; H. Leclerca, Grégoire le Grand, DACL VI 2, 1757.

${ }^{17}$ Por. Epistolae IX 98, X 51, XIV 2, PL 77, 1023D, 1106C, 1305; Prosopography of the Later Roman Empire, III, dz. cyt., (Palatinus).

${ }^{18}$ Por. Joannes Diaconus, Vita Gregorii Magni 19, PL 75, 66A: „In huius sacri monasterii penetralibus idem vir omnipotentis Dei Gregorius, a matre Silvia, tunc temporis iuxta portam beati 
do 572 r., kiedy to została mniszką. Grzegorz bowiem, jak wiadomo, o czym przypomnial również Ojciec Święty Pius X w poświęconej mu encyklice Iucundum sane „był bardzo wątly i słabowity, nawiedzany długimi chorobami, zagrażającymi często jego życiu" ". Zatroskana matka chociaż w tej formie chciała złagodzić jego niedomagania. On natomiast wycofał się wkrótce z życia świeckiego, a w 573 r. dom rodzinny zamienił na klasztor pod wezwaniem św. Andrzeja Apostoła, do którego niebawem sam wstąpił, gdy na jego czele stał „najczcigodniejszy opat” Walencjusz ${ }^{20}$, przechowywaną zaś matczyną srebrną tacę podarował zebrakowi ${ }^{21}$.

Przypuszcza się, że Sylwia zmarła między 592 a 594 rokiem, tzn. datą napisania Dialogów. Świadczyłaby o tym dwukrotna informacja Grzegorza o śmierci ciotki Tarsylli, przy której miała być, jak zaznaczono wyżej, jego matka, wspominana jednak tylko w pierwszej relacji ${ }^{22}$. Nie wiadomo, gdzie Sylwia i jej mąż Gordian zostali pochowani, nieznane są też ich nagrobne epitafia.

Papiez Klemens VIII polecił w 1630 r. wpisać imię św. Sylwii do Martyrologium Romanum na dzień 3 listopada ${ }^{23}$, kiedy to do dziś obchodzi się jej święto. W Rzymie w 1968 r. poświęcono Sylwii kościół parafialny, na Sycylii zaś jest patronką Palermo, w Polsce natomiast jej kult jest nieznany.

Obok zebranych wyżej starożytnych przekazów literackich zachowało się o św. Sylwii również kilka późniejszych pamiątek monumentalnych, ikonograficznych i archeologicznych. Związane są one głównie z dwoma ośrodkami Wiecznego Miasta - z kościołem św. Grzegorza na Clivus Scauri i z kościołem św. Saby na Małym Awentynie, a więc z miejscami jej pobytu i działalności oraz późniejszego kultu.

Piszący w IX wieku biograf Jan Diakon informuje, że jeszcze w jego czasach można było oglądać w klasztorze św. Andrzeja na Clivus Scauri dwa bardzo stare obrazy rodziców Grzegorza, które ten polecił namalować tuż obok fon-

Pauli Apostoli, loco qui dicitur Cella nova, quo hactenus oratorium nomini eius dedicatum est et famosum sancti Sabae confessoris Christi monasterium [...] crudis leguminibus pascebatur"; H. Leclercq, DACL VI 2, 1758; G.B. Proja, BS XI 1082; E. Wuescher-Becci, Santa Silvia, madre di san Gregorio, art. cyt., s. 67.

${ }^{19}$ Por. przytoczony na początku tomu tekst encykliki, s. 10.

${ }^{20}$ Por. Dialogi IV 22, 1.

${ }^{21}$ Por. Joannes Diaconus, Vita Gregorii Magni I 10, PL 75, 66BC: „Rursus vestiarium suum, si forte vas quodlibet aut vestimentum haberet, interrogans, audivit nil penitus remansisse praeter matris argenteam, quae cum infusis leguminibus mitti solita erat, scutellam. Mox alacrior factus, ergo, inquit, frater, hanc defer, ne tristis abeat qui consolari quaerit pauper. Itaque delatam scutellam, Gregorio satis hilariter largiente, pauper, qui putabatur, laetus amplectitur, non jam ad expetenda, sed ad conferenda suffragia rediturus".

22 Por. In Evangelia hom. 38, 1; zob. wyżej n. 2; G.B. Proja, Silvia, BS XI 1082.

${ }^{23}$ Por. Martyrologium Romanum, tłum. P. Turbak, Kraków 1967, 315: „W Rzymie świętej Sylwii, matki św. Grzegorza papieża". 
tanny w atrium klasztornym; w absydzie kościoła za chórem zakonnym widniał również okrągły portret Grzegorza. Sam Jan Diakon musiał je oglądać, skoro tak szczegółowo je opisuje. Pierwszy z nich przedstawiał św. Piotra w pozycji siedzącej i błogosławiącej oraz stojącego obok niego ojca Grzegorza - Gordiana, który ubrany w płaszcz i sandały, o umiarkowanej brodzie i poważnym obliczu, prawą ręką wskazywał na Apostoła ${ }^{24}$. Drugi natomiast obraz, jeszcze szczegółowiej przez biografa opisany, przedstawial siedzącą na tronie Sylwię prawą ręką błogosławiącą a lewą trzymającą otwarty psałterz oraz napis nad głową i ramionami informujący, ze dzieło to matce Sylwii ufundował Grzegorz:

„Na drugim zaś obrazie matka Grzegorza, Sylwia, namalowana w pozycji siedzącej otulona białym welonem tak skierowanym od prawego do lewego ramienia, że pod nim ręka jakby spod płaszcza się wyłaniała; wokół piersi pod szyją widać było spodnią tunikę pseudomlecznego koloru, która wielkim zagięciem spływała na stopy; przyozdobiona dwoma pasami jak na dalmatykach, ale o wiele szerszymi; wzrost pełny, twarz wprawdzie okrągła i jasna, ale sędziwością już pomarszczona; mimo podeszłego wieku była bardzo piękna; o dużych i sowich oczach, małych brwiach, ozdobnych wargach i jasnym spojrzeniu, nosząca na glowie macierzyńską opaskę z jasnego płótna o rzadkiej białości; dwoma palcami prawej ręki zdająca się zabezpieczać znakiem krzyża; w lewej zaś trzymająca otwarty psalterz, w którym jest napisane: „Dusza moja żyje i będzie cię chwalić, a wyroki twoje będą mnie wspomagać" (Ps 118, 175). Od prawego zaś łokcia aź do lewego nad ramionami błyszczy wstępujący werset, który tak oto brzmi: „uczynił to Grzegorz matce Sylwii”25.

Dzięki temu opisowi zachowało się kilka informacji o jej wyglądzie (ryc. 43). Przed naszymi oczyma jawi się kobieta stateczna, której twarz, choć pokryta zmarszczkami, świadczy, iż była niezwykłej urody, o dużych, sowich oczach, delikatnym rysunku brwi i pięknych wargach. Przy opisie dominuje kolor bieli:

${ }^{24}$ Por. Vita Gregorii Magni IV 83, PL 75, 229B: „In cujus venerabilis monasterii atrio, jussu Gregorii, juxta nymphium duae iconiae veterrimae artificialiter depictae usque hactenus videntur. In quarum altera beatus Petrus apostolus sedens conspicitur, stantem Gordianum, regionarium, videlicet patrem Gregorii, manu dextera per dexteram nihilominus suscepisse. Cujus Gordiani habitus castanei coloris planeta est, sub planeta dalmatica, in pedibus caligas habens; statura longa, faciem deducta, virides oculi, barba modica, capilli condensi, vultus gravis".

${ }^{25}$ Tamże, PL 75, 229C-230A: „In altera vero mater Gregorii sedens depicta est Silvia, candido velamine a dextro humero taliter contra sinistram revoluto contecta, ut sub eo manus tamquam de planeta subducat; et circa pectus sub gula interior tunica pseudolactini coloris appareat, quae magno sinuamine super pedes defluat; duabus zonis ad similitudinem dalmaticarum, sed latioribus omnino distincta; statura plena, facies rotunda quidem et candida, sed senio jam rugosa, quam ipsa quoque senectus pulcherrimam fuisse significat; oculis glaucis et grandibus, superciliis modicis, labellis venustis, vultu hilari, ferens in capite matronalem mitram candentis brandei raritate niblatam; duobus dexterae digitis signaculo crucis se munire velle praetendens, in sinistra vero patens psalterium retinens, in quo hoc scriptum est: Vivit anima mea, et laudabit te, et judicia tua adiuvabunt me (Ps 108, 175). A dextero vero cubito usque ad sinistram circa scapulas versus ascendens reflectitur, qui ita se habet: Gregorits Silviae matri fecit". Opis portretu Grzegorza por. tamże, IV 84, PL 75, 230BC. 
biały welon, pseudomleczna tunika, biała opaska na głowie. Jej spojrzenie również było jasne, a dusza otwarta, by wielbić Boga. Wszystkie te nie istniejące już dziś obrazy, opierając się na powyższych opisach, próbował odtworzyć na początku XX wieku E. Wuescher-Becchi ${ }^{26}$, a rekonstrukcje te powtórzył później $H$. Leclercq w swoim haśle o św. Grzegorzu Wielkim ${ }^{27}$.

Gdy w nieznanych nam okolicznościach zaginęły opisane przez Jana Diakona obrazy Grzegorza i jego rodziców, a potrzeby kultu tego wymagały, w XVI wieku można było zobaczyć w kościele św. Grzegorza na Clivus Scauri inny późniejszy jego obraz z rodzicami. Według kardynała Fryderyka Boromeusza (1564-1631), który go oglądał, miał on być „,bardzo podobny do obrazu świętego, jaki opisał Jan Diakon"28. W 1597 r., opisal go a nawet umieścil na okładce swej książki poświęconej św. Grzegorzowi i jego rodzicom tytularny biskup Tagasty Angelo Rocca ${ }^{29}$. Nie był to jednak, mimo zapewnień o wierności, ten sam obraz odtwarzający obrazy opisane przez Jana Diakona, bo w przeciwieństwie do tamtych, wszystkie trzy święte postacie znajdują się na jednym obrazie i to w pozycji stojącej (ryc. 44), ubrane inaczej, a pierwowzór opisany przez biografa ukazywał św. Sylwię siedzącą na tronie. Olejną kopię tego obrazu znajdujemy w kościele św. Saby na Małym Awentynie.

Św. Sylwia w klasztorze na Wzgórzu Skaurusa uwieczniona była nie tylko na obrazach, ale w późniejszym czasie miała również własne sanktuarium. Wspominaliśmy wyżej, że Grzegorz po „nawróceniu” zamienił swój dom na klasztor, w którym przestrzegano reguły św. Benedykta ${ }^{30}$. Nosił on nazwę klasztoru św. Andrzeja, a od 976 r. również św. Grzegorza (monasterium

${ }^{26}$ Por. E. Wuescher-Becchi, Sulla ricostruzione di tre dipinti descritti da Giovanni Diacono ed esistenti al suo tempo (sec. IX) nel convento di S. Andrea ad Clivum Scauri, „Nuovo Bullettino di Archeologia Cristiana" 6 (1900) 235-251.

${ }^{27}$ Por. H. Leclercq, Grégoire le Grand, DACL VI 2, 1763-1767.

${ }^{28}$ Por. De pictura sacra, t. 2: Symbolae litterariae opuscula varia, Roma 1784, 76: „Romae, iam prope aedem S. Gregorii effigies Sancti ipsius antiquissima cernebatur, quae licet, ob artifices fortasse inscitam non ipsum plane referret. Simillima tamen erat sancti eius imagine, quam Iohannes Diaconus stylo expressit, nec melior utique vetustiorque alia exstabat. Iam eo apparere desiit ob ruinas volumusque nos in hunc librum eam includere"; cytuję za: E. Wuescher-Becchi, Santa Silvia, madre di san Gregorio, art. cyt., s. 64.

${ }^{29}$ Por. A. Rocca, S. Gregorii eiusdem parentum imagines, Romae 1597: „Quamvis autem dictae imagines a Ioh. Diac. descriptae, non eodem in loco essent, eas tamen hoc disposui ordine, juxta quem in aedicula S. Andreae pictas Romae inveni; haec namque circa 300 annos ex iis, quas Iohannes sua tempestate in atrio monasterii existisse testatur, desumptae videntur a pictore tamen non satis perito, sicut res minus aptae, minusve ad artem pictoriam pertinentes id nobis persuadent [...]. Quoniam autem in monasterio dictae imagines pictae fuerint, non satis constat", cytuję za: E. Wuescher-Becchi, jw., s. 66-67.

30 Por. Liber Pontificalis 66, ed. Duchesne 1312: „Hic domum suam constituit monasterium”; Joannes Diaconus, Vita Gregorii Magni I 6, PL 75, 65A: ,,intra Romanae urbis moenia sub honore sancti Andreae Apostoli, juxta basilicam sanctorum Joannis et Pauli ad clivum Scauri, monasterium in proprio domatae fabricavit". 
S. Andreae et Gregorii, qui politur in Clivo Scauri), któremu w XVII wieku dedykowano także kościól ${ }^{31}$. Przy tym kościele, na lewo, od prowadzących do niego monumentalnych schodów, znajdują się trzy kaplice (sanktuaria), dedykowane św. Andrzejowi, św. Barbarze i św. Sylwii, które w swym aktualnym stanie nie sięgają dalej, jak XVI wieku. $\mathrm{O}$ istnieniu dwóch pierwszych wspominał już biograf Jan Diakon ${ }^{32}$.

Kaplica w środku poświęcona św. Andrzejowi i Matce Bożej - to pierwotne oratorium konwentu założonego przez św. Grzegorza w domu swoich przodków. Na lewo od niej znajduje się kaplica św. Barbary połączona z poprzednią za pośrednictwem starożytnych murów; obie odbudowane zostały na wcześniejszych fundamentach przez kardynała Baroniusza (1607), który zarządzal opactwem na Clivus Scauri. Trzecia wreszcie kaplica na prawo, calkowicie nowożytna, wzniesiona od fundamentów przez kardynała Baroniusza, dedykowana została matce Grzegorza. Znajduje się w niej statua św. Sylwii dhuta Niccolo Cordieriego (ryc. 45) zwanego Franciosino (1567-1612), ucznia Michała Anioła. Święta przedstawiona jest w pozycji stojącej, przybrana w piękne szaty. Jej spojrzenie wznosi się ku niebu, prawą rękę trzyma na piersi, zaś w lewej - otwartą księgę z wyrytym zdaniem z psalmu: „Vivet anima mea et laudabit te et iudicia tua adiuvabunt me" (Ps 118, 175) ${ }^{33}$. N. Cordieri rzeźbiąc tę statuę miał prawdopodobnie przed oczyma XVI-wieczny obraz św. Grzegorza $z$ matką ze znajdującego się obok jego kościoła, gdzie Sylwia przedstawiona jest również $z$ otwartym psałterzem.

Drugim rzymskim miejscem, związanym ze św. Sylwią, jest kościół św. Saby na Małym Awentynie. To tutaj, jak informuje biograf, matka Grzegorza po śmierci męża Gordiana zamieszkała samotnie „w miejscu zwanym Cella Nova", a które w IX wieku stanowilo „sanktuarium poświęcone jej imieniu” (oratorium domini eius dedicatum) $^{34}$. W poszukiwaniu ostatniego miejsca zamieszkania i sanktuarium Sylwii przeprowadzono w latach 1901-1902 wykopaliska pod aktualnym kościołem św. Saby. W jego nawie głównej 2 metry pod posadzką odkryto średniej wielkości $(10 \times 13,5 \mathrm{~m})$ jednonawowe bezkolumnowe prostokątne oratorium wczesnochrześcijańskie $z$ obszerną półokrągłą absydą i resztkami malowideł na ścianach (ryc. 46). Oratorium to, wzniesione w VII wieku przez mnichów greckich, służyło im do początków XII wieku ${ }^{35}$;

${ }^{31}$ Por. R. Krautheimer, Corpus Basilicarum christianarum Romae, I, Città del Vaticano 1937, 317-323 (S. Gregorio Magno); Ch. Huelsen, Le chiese di Roma nel Medio Evo, Roma 2000, 256-257 (S. Gregorii in clivo Scauri).

32 Vita Gregorii Magni IV 89, PL 75, 234B: „Eodem tempore post absidem oratorii sanctae Mariae semper Virginis oratorio sanctae Barbarae, ubi Gregorius laudes Domino celebrare solebat".

${ }^{33}$ Por. E. Wuescher-Becchi, Santa Silvia, madre di san Gregorio, art. cyt., s. 60-62.

${ }^{34}$ Por. wyżej n. 18.

35 Por. A. Antonelli, I primi monasteri di monaci orientali a Roma, „Rivista di Archeologia Cristiana" 5 (1928) 114-121 (Monastero di S. Saba sull'Aventino); J. Lestocquoy, Notes sur l'Eglise 
potem przejęli je w 1145 r. benedyktyńscy mnisi kluniaccy, którzy zbudowali tu nowy, aktualny kościól, dedykowany św. Sabie.

Dom św. Sylwii usytuowany był z lewej strony oratorium, gdzie odkryto charakterystyczną konstrukcję złączoną obecnie z lewą nawą kościoła i oddzieloną od niej starożytnymi kolumnami i łukami. To wszystko dowodzi, że wcześniej przed kościołem św. Saby znajdowały się tutaj dom i oratorium św. Sylwii (ryc. 47), oddane po jej śmierci bazylianom, którzy przenieśli później na Mały Awentyn swój klasztor ${ }^{36}$. W kościele tym na lewo od głównego oltarza znajduje się kaplica św. Sylwii, a w jej ołtarzu olejny XVI-wieczny obraz, będący wierną kopią zaginionego, ale zrekonstruowanego w 1597 r. przez biskupa A. Rocchę obrazu św. Grzegorza i jego rodziców, który umieścil wówczas pod nimi następującą inskrypcję: „Imagines S. Gregorii, Gordiani ejus patris et B. Silviae matris, singularis Revmi D.F. Angeli Rocchae episcopi Tagastensis et S.D.N. sacristae industria, ex edicula S. Andreae prope ejusdem S. Gregorii ecclesiam ad vivum expressae". Obraz przedstawia trzy stojące podpisane na dole postacie (ryc. 44): w środku św. Grzegorz w metropolitalnym ornacie trzymający na lewym ramieniu księgę, a prawą ręką błogosławiący; po jego prawej stronie Gordian z lewą ręką wyciągniętą do syna (Gordianus $S$. Gregorii pater), po lewej zaś Sylwia z otwartym psałterzem (Silvia S. Gregorii mater) ${ }^{37}$.

Z późniejszych przedstawień ikonograficznych św. Sylwii ${ }^{38}$, na szczególną uwagę zasługują dwa obrazy: Johna Parkera (1730-1765) i A. Moretta z Brescii (1498-1554). J. Parker, przebywający dłuższy czas w Rzymie, namalował dla kościoła św. Grzegorza na Monte Celio słynny obraz ołtarzowy (za który m.in. został przyjęty w poczet czlonków Akademii św. Łukasza), przedstawiający św. Sylwię ofiarującą syna Grzegorza św. Benedyktowi (ryc. 48). Sylwia ukazana jest jako mloda kobieta o długich, ciemnych włosach spływających na ramiona; bosa, ubrana w długą drapowaną suknię, siedzi na posadzce a obok niej stoi mały Grzegorz, również boso, w długiej sukni z wyciągniętymi przed siebie rękami. Matka prawą rękę trzyma na ramieniu synka, lewą zaś rozkłada jakby bezradnie. Wzrok ich obojga skierowany jest w górę, w stronę św. Benedykta, wznoszącego lewą rękę ku gołębicy otoczonej promieniami jasnego światła. Św. Benedyktowi towarzyszy klęcząca na chmurze postać z tiarą w rękach, za jego plecami natomiast putto trzyma pastorał.

de Saint Saba, tamże 6 (1929) 313-357, spec. 315-321 (L'oratoire dit „De sainte Sylvie”); G. Wilpert, Le pitture dell'oratorio di S. Silvia, ,Mélanges d'Archéologie et d'Histoire" 26 (1906) 15-26; G. Ferrari, Early Roman Monasteries, Città del Vaticano 1957, 281-290 (St. Saba); Ch. Huelsen, Le chiese di Roma nel Medio Evo, Roma 2000, 429-430 (S. Saba); H. Leclercq, Grégoire le Grand, DACL VI 2, 1761-1765.

${ }^{36}$ Por. E. Wuescher-Becchi, Santa Silvia, madre di san Gregorio, art. cyt., s. 68-70.

37 Por. H. Leclercq, Grégoire le Grand, DACL VI 2, 1761-1765; E. Wuescher-Becchi, Santa Silvia, madre di san Gregorio, art. cyt., s. 66.

38 Por. C. Ricci, Mille Santi nell'arte, Milano 1931; A.M. Raggi, BS XI 1083-1084; L. Réau, Iconographie de l'art chrétien, Paris 1959, III 1242. 
Ciekawym przedstawieniem ikonograficznym, na którym zaznaczona została obecność św. Sylwii, jest również obraz A. Moretta z Brescii (1498-1554), zwanego Romanino - Koronacja Najświętszej Maryi Panny, znajdujący się w kościele pod wezw. św. Jana Ewangelisty w Brescii (ryc. 49). Centralną sceną półkolistego w kształcie malowidła jest koronacja przez Jezusa Chrystusa Zmartwychwstałego swojcj Matki - Maryi w obecności Boga Ojca siedzącego na tronie. Bóg Ojciec w tej scenie - to frontalnie przedstawiony starzec o dlugiej, siwej brodzie i wąsach, w ozdobnej brązowej szacie trzymający prawą rękę na plecach Maryi. U Jego stóp klęczą Jezus i Maryja. Matka Jezusa ukazana z zamkniętymi oczami i skrzyżowanymi rękami, o szatynowych wlosach, w ciemnoczerwonej sukni i czarnym lamowanym plaszczu pochyla się w stronę Syna, przyjmując $z$ Jego rąk koronę. Jezus przedstawiony jest $z$ dlugimi brązowymi włosami i brodą, w dlugiej tunice, ze spadającym $z$ ud czerwonym drapowanym plaszczem. Po obu stronach tronu rozgrywającą się scenę koronacji adorują na kolanach i w modlitewnym skupieniu postacie świętych doktorów Kościoła wraz ze swoimi matkami - po lewej św. Augustyn, ukazany w stroju biskupim jako brodaty mężczyzna w średnim wieku, $\mathrm{z}$ tonsurą na głowie, ubrany w purpurową kapę, ozdobioną motywami roślinnymi, trzymający w lewej ręce pastoral, z mitrą leżącą u jego stóp; towarzyszy mu matka - św. Monika, przedstawiona jako starsza kobieta, ze wzrokiem wzniesionym ku górze, w ciemnej szacie i z przezroczystym bialym welonem na głowie. Podobnie scharakteryzowane i symetrycznie do tronu umieszczone są postacie po prawej stronie obrazu: postać starca - św. Grzegorza Wielkiego, z tonsurą, ubranego w czarną kapę. obramowaną u dołu czerwoną lamówką, miękko spływającą na gzyms; święty klęczy z rękami złożonymi do modlitwy, ujmując nimi również pastorał; na lewym ramieniu przysiadła biała gołębica (symbol Boskiego natchnienia), a u jego stóp, na fragmencie kapy, spoczywa tiara (symbol najwyższej godności w Kościele); obok papieża, bliżej głównej sceny, klęczy modląca się jego matka św. Sylwia; jej ciało spowija strój mniszy (czarny habit, szyję i dekolt przykrywa biały tok, włosy zaś okrywa czarny welon). Całości kompozycji po lewej i prawej stronie towarzyszą klęczący mnisi w białych habitach ze szkaplerzami, dopelniają ją równiez dwa małe anioły siedzące na gzymsie w centrum sceny, u stóp Jezusa i Maryi. Nieziemski wymiar dziela podkreśla błękitne tło z oryginalnymi purpurowo-pomarańczowymi chmurami. Scena jest symboliczną wizją Koronacji Najświętszej Maryi Panny, rozgrywającej się w niebieskiej rzeczywistości po Zaśnięciu Maryi, a gromadzącej Zmartwychwstałego Jezusa Chrystusa, naznaczonego śladami swej męki (widoczna przebita na krzyżu lewa ręka Zbawicicla), w szczególny sposób wyróżniającego swoją Matkę (nałożenie korony), a także świadków tej uroczystości - wielkich doktorów Kościoła, którym wiarę w Najwyższego przekazały matki - św. Monika i św. Sylwia.

Obie matki dożyły starości, mogły więc wspierać modlitwą swoich synów. $\mathrm{Z}$ przekazów tak wiele wicmy o św. Monice, a tak niewiele o św. Sylwii. Ta 
znikoma ilość informacji źródłowych o matce Grzegorza nie pozwoliła na szersze ukazanie jej sylwetki.

\section{HEILIGE SILVIA, MUTTER DES PAPSTES GREGOR DES GROSSEN}

\section{(Zusammenfassung)}

Das im Aufsatz dargestellte Bild der hl. Silvia, der Mutter des Papstes Gregor des Grossen setzt sich sowohl aus Informationen aus literarischen Quellen zusammen - stammend vom Gregor persönlich und von seinem Biographen Johann Diakon - als auch aus der Tradition, die sich in der Ikonographie ausdrückt und besonders mit zwei Orten in Rom verbunden ist: Clivius Scauri (Kirche S. Gregor) und Kleiner Aventin (Kirche S. Saba), bekannt durch Aufenthalt und Kult der Heiligen. Aus einigen späteren ikonographischen Darstellungen wurde die Aufmerksamkeit auf zwei Bilder gerichtet, auf denen die Gestalt der Mutter des hl. Gregors verewigt ist : die Krönung der Heiligen Jungfrau von A. Moretti di Brescia und Silvia opfernde ihr Kind dem hl. Benedikt von J. Parker. 